\title{
PENGARUH EARNING PER SHARE DAN PRICE TO BOOK VALUE TERHADAP HARGA SAHAM PT. PEMBANGUNAN PERUMAHAN, TBK
}

\author{
Diah Juliningtias ${ }^{1}$ ) \\ 1) Mahasiswa Program Studi Manajemen FE UNKRIS \\ Sunartiyo ${ }^{2}$ ) \\ 2) Dosen Program Studi Manajemen FE UNKRIS \\ Alamat: Kampus UNKRIS, Jatiwaringin Jakarta Timur \\ Email : tivosunartivo85238@gmail.com
}

\begin{abstract}
This research aim to to check influence, monunt earning per share and price to book value to price Share of PT. Pembangunan Perumahan, TBK. Methode analyse data used in this research is methode of dobled linier represi to anticipate influence frome some Independent variable either through persial and also by simultan to variable dependent. This finding yield that by simultan is inflnence af Independent variable (earning per share and price to book value to price Share) having on effect on positif and significan to variable dependence (Share Price)
\end{abstract}

Keywords: Earning pershare, price to book value, harga saham

\section{PENDAHULUAN}

Salah satu instrument pasar modal yang paling diminati investor adalah saham. Saham yang beredar memiliki nilai yang disebut dengan harga saham. Menurut Dominic (2008) harga saham selalu berfluktuasi setiap hari baik pada periode pasar sedang bullish (menanjak) maupun bearish (menurun). Harga saham berubah karena hukum supply (penawaran) dan demand (permintaan). Jika lebih banyak orang yang ingin membeli suatu saham, harganya akan naik. Jika lebih banyak orang yang ingin menjual suatu saham, harganya akan turun.

Salah satu faktor yang mempengaruhi harga saham adalah kinerja keuangan perusahaan. Kinerja keuangan dengan cara menganalisis rasio keuangan perusahaan. Hanafi (2015) mengelompokkan analisis keuangan menjadi lima bagian yaitu rasio likuiditas, rasio leverage, rasio aktivitas, rasio profitabilitas dan rasio pasar.

Rasio pasar merupakan sekumpulan rasio yang digunakan untuk mengestimasi nilai instrinsik perusahaan (nilai saham). Rasio ini memberi petunjuk mengenai apa yang dipikirkan investor atas kinerja perusahaan di masa lalu serta prospek di masa mendatang (Moeljadi, 2006), selain itu rasio pasar juga menjadi indikator untuk mengukur mahal murahnya suatu saham. Rasio pasar yang dilakukan dipenelitian ini adalah earning per share (EPS). Earning per share merupakan rasio yang menunjukkan kemampuan perusahaan dalam memperoleh keuntungan bagi pemegang saham (Kasmir, 2018). Earning per share atau laba per lembar saham dapat digunakan untuk memberikan infomasi bagi investor dalam mengetahui perkembangan dari perusahaan. Menurut Syamsuddin (2013) para calon pemegang saham tertarik dengan earning per share yang besar, karena hal ini merupakan salah satu indikator keberhasilan suatu perusahaan. 
Selain nilai earning per share, nilai price to book value juga dapat digunakan untuk mengukur kinerja harga saham. Nilai price to book value menunjukkan seberapa jauh perusahaan mampu menciptakan nilai perusahaan relatif terhadap jumlah modal yang diinvestasikan jika nilai buku suatu perusahaan meningkat maka nilai perusahaan yang ditunjukan dengan harga saham akan meningkat maka nilai perusahaan yang ditunjukkan dengan harga saham akan meningkat pula. (Najmiyah et.al., 2014).

Penelitian tentang hubungan earning per share dengan harga saham telah dilakukan sebelumnya. Salah satunya oleh Aisyatur dan Sulasmiyati (2018), hasilnya menyatakan bahawa earning per share berpengaruh positif terhadap harga saham, sedangkan hasil berbeda ditemukan oleh Khairani (2016) yang menyebutkan bahwa earning per share tidak berpengaruh terhadap harga saham. Penelitian mengenai hubungan price to book value dengan harga saham juga telah dilakukan sebelumnya. Salah satunya oleh Yustina dan Tiara (2015), hasilnya menyatakan bahwa price to book value berpengaruh positif terhadap harga saham. Sedangkan hasil berbeda ditemukan oleh Abimantara (2013) yang menunjukkan bahwa variabel price to book value tidak berpengaruh secara signifikan terhadap harga saham. Penelitian ini dilakukan pada PT Pembangunan Perumahan (Persero) Tbk. PT PP (Persero) Tbk yang merupakan perusahaan pelaksana kontribusi bangunan gedung dan sipil. Dan saat ini PT PP (Persero) Tbk juga merupakan perusahaan investasi. Secara umum perusahaan konstruksi memberikan kontribusi yang cukup besar terhadap tingkat PDB di Indonesia, selain industri pengolahan.

Untuk sektor konstruksi, pada tahun 2018 masih bertumbuh namun mengalami pelemahan. Berdasarkan data yang dirilis Badan Pusat Statistik (BPS), sektor konstruksi memberikan konstruksi sebesar 6,09\%, turun dibandingkan capaian 10,38\% tahun 2017. Sementara kontribusinya terhadap pertumbuhan ekonomi nasional juga menurun dari 0,67\% tahun 2017 menjadi 0,64\% Th 2018. Walapun demikian, Sektor konstruksi masih memiliki potensi yang sangat besar menyusul berlanjutnya pembangunan infrastruktur. Sektor konstruksi masih memberikan konstribusi yang besar dalam bisnis PTPP. Adapun Sektor konstruksi PTPP meliputi meliputi konstruksi regular, konstruksi EPC, Pracetak dan Kontraktor berbasis alat berat.

Tujuan penulisan ini untuk mengetahui berapa besar pengaruh varibel indepeden (earning per share dan price to book value) terhadap harga saham (variabel dependen) secara semultan dan parsial.

\section{LANDASAN TEORI}

\section{Harga Saham}

Harga saham merupakan harga penutupan pasar selama periode pengamatan untuk tiap-tiap jenis saham yang dijadikan sampel dan pergerakannya senantiasa diamati oleh inverstor. Harga Saham menurut Husnan dan Pudjiastuti (2015) adalah "Merupakan nilai sekarang (present value) dari penghasilan yang akan diterima oleh pemodal dan diterima oleh pemodal di masa akan yang akan datang". Menurut Sartono (2008) menyatakan bahawa "Harga saham terbentuk melalui mekansime permintaan dan penawaran, maka harga saham cenderung naik. Sebalikanya apabila kelebihaan penawaran maka harga saham cendurung turun", Harga saham memiliki kaitan yang erat dengan harga pasar suatu saham. Menurut Jogiyanto (2016) harga saham. Di Bursa efek akan ditentukan oleh kekuatan permintaan dan penawaran saham yang bersangkutan di pasar modal. Pada saat pemintaan atas suatu saham meningkat, maka harga saham tersebut akan cenderung meningkat. Sebaliknya, pada saat lebih banyak orang yang menjual saham tersebut 
dibandingkan dengan orang yang berminat membelinya, maka harga saham tersebut cenderung mengalami penurunan.

\section{Earning Per Share}

Earning per share merupakan kelompok dalam rasio pasar yang menunjukkan pengakuan pasar terhadap kondisi keuangan yang dicapai perusahaan atau mengukur kemampuan manajemen dalam menciptakan nilai pasarnya di atas biaya investasi (Putra, 2014). Earning per share merupakan rasio untuk mengukur keberhasilan manjemen dalam mencapai keuntungan bagi pemegang saham (Kasmir, 2018). Rasio yang rendah berarti manjemen belum berhasil untuk memuaskan pemegang saham, sebaliknya dengan rasio yang tinggi, kesejahteraan pemegang saham meningkat. Dengan pengertian lain, tingkat pengembalian yang tinggi.

Keuntungan bagi pemegang saham adalah jumlah keuntungan setelah dipotong pajak. Keuntungan yang tersedia bagi pemegang saham biasa adalah jumlah keuntungan dikurangi pajak, dividen, dan dikurangi hak-hak lain untuk pemegang saham prioritas. Rumus untuk mencari laba per lembar saham adalah sebagai berikut (Siwoyo, 2013):

$$
\text { EPS }=\frac{\text { Laba Bersih }}{\text { Jumlah Saham beredar }}
$$

Pada umumnya manajemen perusahaan, pemegang saham dan calon pemegang saham sangat tertarik akan earning per share, karena hal ini menggambarkan jumlah rupiah yang diperoleh untuk setiap lembar saham. Para calon pemegang saham tertarik dengan earning per share yang besar, karena hal ini merupakan salah satu indicator keberhasilan suatu perusahaan. Nilai earning per share yang meningkat menandakan bahwa perusahaan tersebut akan memberikan prospek laba yang besar kepada investor. Hal ini mendorong para investor untuk menambah jumlah permintaan terhadap saham mendorong harga saham naik. Semakin kecil nilai earning per share menunjukkan semakin kecil laba yang disediakan untuk investor sehingga dapat menurunkan harga saham karena menurunnya minat investor untuk membeli saham.

\section{Price to Book Volue}

Nilai buku per lembar saham menunjukkan aktiva bersih yang dimiliki oleh pemegang saham dengan memiliki satu lembar saham. Karena aktiva bersih adalah sama dengan total ekuitas pemegang saham, maka nilai buku per lembar saham adalah total ekuitas dibagi dengan jumlah saham yang beredar (Jogiyanto, 2003). Book value (BV) per lembar saham yang diterbitkan pada dasarnya mewakili jumlah asset/ekuitas yang dimiliki perusahaan tersebut.

Mengetahui book value dari suatu saham bukan saja penting untuk mengetahui kapasitas dari harga per lembar suatu saham. Ini juga penting untuk digunakan sebagai tolak ukur dalam menentukan wajar atau tidaknya harga saham dipasar (market value).

Rumus:

$$
\text { Total Ekuitas }
$$

$$
\mathrm{BV}=\overline{\text { Jumlah saham yang beredar }}
$$


Pengertian price to book value menurut Husnan dan Pudjiastuti (2006): "Price to book value merupakan perbandingan antara harga pasar dan nilai buku saham. Untuk perusahaan-perusahaan yang berjalan dengan baik, umumnya rasio ini mencapai diatas satu, yang menunjukkan bahwa nilai pasar saham lebih besar dari nilai bukunya. Semakin besar rasio price to book value semakin tinggi, perusahaan dinilai oleh para pemodal relatif dibandingkan dengan dana yang telah ditanamkan di perusahaan." Menurut Tandelilin (2010): "Hubungan antara harga pasar saham dan nilai buku per lembar saham bisa juga dipakai sebagai pendekatan alternatif untuk menentukan nilai suatu saham, karena secara teoritis, nilai pasar suatu saham haruslah mencerminkan nilai bukunya."

Price to book value merupakan perbandingan antara harga per lembar saham dengan nilai buku per lembar saham. Darmadji dan Fakhruddin (2011) mendefinisikan price to book value merupakan rasio yang menggambarkan seberapa besar pasar menghargai nilai buku saham dari perusahaan. Perhitungan harga saham yang dipakai adalah dipakai adalah harga saham pada penutupan periode tertentu. Harga saham yang dimaksud adalah nilai saham yang tertera di pasar sedangkan nilai buku adalah perbandingan antara nilai ekuitas dengan jumlah saham beredar. Menurut Husnan dan Pudjiastuti (2006), rumus yang digunakan untuk menghitung price to book value adalah sebagai berikut:

$$
\text { PBV }=\frac{\text { Harga Pasar }}{\text { Nilai Buku Saham }}
$$

Menurut Damodaran (2001) dalam Hidayati (2010) price to book value mempunyai beberapa keunggulan sebagai berikut : 1). Nilai buku mempunyai ukuran intutif yang relatif stabil yang dapat diperbandingkan dengan harga pasar. Investor yang kurang percaya dengan metode discounted cash flow dapat menggunakan price to book value sebagai perbandingan. 2). Nilai buku memberikan standar akuntansi yang konsisten untuk semua perusahaan price to book value dapat diperbandingkan antara perusahaanperusahaan yang sama sebagai petunjuk adanya under atau overvaluation.

\section{METODE PENELITIAN}

\section{Data dan Sumber Data}

Dalam penelitian ini, pengumpulan bersumber data sekunder seperti profil PT Pembangunan Perumahan (Persero) Tbk, laporan keuangan per quarterly PT Pembangunan Perumahan (Persero) Tbk, dan harga saham penutupan per quarterly PT Pembangunan Perumahan (Persero) Tbk di BEI (Bursa Efek Indonesia) periode 2010 sampai 2018. Sebagai landasan teori, penulis menggunakan buku literatur, jurnal-jurnal serta penelitian sebelumnya.

\section{Teknik Analisis Data}

Penelitian ini akan menggunakan teknik analisis regresi, korelasi, uji determinasi dan uji signifikan. 


\section{HASIL DAN PEMBAHASAN}

\section{Tabel-1}

Data Variabel Rata-Rata, Harga Saham, EPS, dan PBV

PT Pembangunan Perumahaan (Persero) Tbk

Tahun 2010-2018 (Sudah di Tranformasi)

\begin{tabular}{cccc}
\hline Tahun & Harga Saham $(\boldsymbol{\%})$ & EPS $(\boldsymbol{\%})$ & PBV $(\boldsymbol{\%})$ \\
\hline 2010 & 6.65 & 2.89 & 4.11 \\
2011 & 6.31 & 3.14 & 2.22 \\
2012 & 6.35 & 3.47 & 2.36 \\
2013 & 0.19 & 4.01 & 3.42 \\
2014 & 0.85 & 4.25 & 5.52 \\
2015 & 1.30 & 4.49 & 6.19 \\
2016 & 1.37 & 4.55 & 3.78 \\
2017 & 1.05 & 5.23 & 1.52 \\
2018 & 0.69 & 5.21 & 0.84 \\
\hline
\end{tabular}

Sumber: Data di olah

Uji hipotesis diperoleh hasil, F hitung $36.064>\mathrm{F}$ tabel 3,286 berarti berpengaruh signifikan price to book value dan earning per share terhadap harga saham PT Pembangunan Perumahan (Persero) Tbk.

Uji regresi linier berganda digunakan untuk mengetahui pengaruh price to book value dan earning per share terhadap harga saham PT Pembangunan Perumahan (Persero) Tbk. Hasil analisis regresi berganda di peroleh persamaan liniernya Sbb:

$$
\mathrm{Y}=4,270+0,617\left(\mathrm{X}_{1}\right)+0,174\left(\mathrm{X}_{2}\right)
$$

Konstanta yang diperoleh sebesar 4,270 dengan tanda positif, sehingga besaran konstanta menunjukkan bahwa jika tanpa earning per share dan price to book value, maka harga saham sebesar 4,270 persen.

Koefisien regresi earning per share adalah sebesar 0,617 bertanda positip. Koefisien regresi 0,617 dapat diartikan bahwa setiap kenaikan satu persen earning per share maka harga saham akan naik sebesar 0,617 persen, dengan asumsi price to book value tetap.

Koefisien regresi price to book value adalah sebesar 0,174 bertanda positif. Konefisien regeresi 0,174 dapat diartikan bahwa setiap kenaikan satu persen price to book value maka harga saham akan naik sebesar 0,174 persen dengan asumsi earning per share tetap.

Korelasi dan koefisien determinasi dapat dilihat pada tabel di bawah ini : Secara Simultan

Tabel-2

Output Koefisien Korelasi dan Determinasi Berganda Model Summary

\begin{tabular}{rrrrr}
\hline Model & R & R Square & $\begin{array}{c}\text { Adjusted R } \\
\text { Square }\end{array}$ & $\begin{array}{l}\text { Std.Error of } \\
\text { the Estimate }\end{array}$ \\
\hline 1 & $.828 \mathrm{a}$ & .686 & .667 & .42699 \\
\hline
\end{tabular}

a. Predictors (Constant), PBV, EPS

Sumber : data diolah dengan SPSS 25.0 
Berdasarkan Tabel-2, dapat diketahui bahwa secara simultan keeratan hubungan yang terjadi antara Earning Per Share dan Price to Book Value terhadap harga saham PT Pembangunan Perumahan (Persero) Tbk adalah sangat kuat dan positif. Dengan nilai koefisien korelasi berganda yang diperoleh (R) sebesar 0,828. Arah hubungan positif yang diperoleh dapat diartikan jika. Earning Per share dan Price to Book Value perusahaan meningkat maka akan meningkatkan harga saham perusahaan juga, demikian sebaliknya jika Earning Per Share dan Price to Book Value perusahan turun maka harga saham perusahaan akan turun juga. Secara simultan earning per share dan price to book value terhadap harga saham PT Pembangunan Perumahan (Persero) Tbk memberikan kontribusi sebesar 0,686 atau 68,6\%, sedangkan sisa sebesar 31,4\% dijelaskan oleh variabel lain yang tidak dibahas dalam penelitian ini.

\section{Earning Per Share}

Uji regresi linier sederhana digunakan untuk mengetahui pengaruh earning per share terhadap harga saham PT Pembangunan Perumahan (Persero) Tbk. Hasil analisis regresi berganda di peroleh persamaan liniernya Sbb:

$$
\mathrm{Y}=14,333-2,799\left(\mathrm{X}_{1}\right)
$$

Konstanta yang diperoleh sebesar 14,333 dengan tanda positif, sehingga besaran konstanta menunjukkan bahwa jika tanpa earning per share, maka harga saham sebesar 14,333 persen. Koefisien regresi earning per share adalah sebesar 2,799 bertanda negatif. Koefisien regresi 2,799 dapat diartikan bahwa setiap kenaikan satu persen earning per share, maka harga saham akan turun sebesar 2,799 persen.

Tabel-3

Output Koefisen Korelasi dan Determinasi EPS Model Summary

\begin{tabular}{|c|c|c|c|c|}
\hline Model & $\mathbf{R}$ & R Square & $\begin{array}{c}\text { Adjusted R } \\
\text { Square }\end{array}$ & $\begin{array}{l}\text { Std.Error of } \\
\text { the Estimate }\end{array}$ \\
\hline 1 & $.704 a$ & .495 & .480 & .53340 \\
\hline
\end{tabular}

Berdasarkan Tabel-3, dapat diketahui bahwa secara parisal keeratan hubungan earning per share terhadap harga saham PT Pembangunan Perumahan (Persero) Tbk adalah kuat dan positif. Dengan nilai koefisien korelasi yang diperolah (R) sebesar 0,704. Arah hubungan positif yang diperoleh jika earnig per share Perusahaan meningkat maka akan meningkatkan harga saham perusahaan, demikian pula sebaliknya jika earning per share turun maka harga saham akan turun juga. Secara parsial eraning per share perusahaan hanya mampu memberikan kontribusi terhadap harga saham perusahaan sebesar 0,495 atau $49,5 \%$, sedangkan sisanya 50,5\% disumbangkan oleh variabel yang tidak diteliti dalam penelitian ini. Uji hipostesi diperoleh t hitung 5,776 > 1,690 t tabel, berarti berpengaruh signifikan. 


\section{Price to Book Value}

Uji regresi linier sederhana digunakan untuk mengetahui pengaruh price to book value terhadap harga saham PT Pembangunan Perumahan (Persero) Tbk. Hasil analisis regresi berganda di peroleh persamaan liniernya Sbb:

$$
\mathrm{Y}=3,452-0,210\left(\mathrm{X}_{2}\right)
$$

Konstanta yang diperoleh sebesar 3,452 dengan tanda positif, sehingga besaran konstanta menunjukkan bahwa jika tanpa price to book value, maka harga saham sebesar 3,452 persen. Koefisien regresi earning per share adalah sebesar 0,210 bertanda negatif. Koefisien regresi 0,210 dapat diartikan bahwa setiap kenaikan satu persen price to book value, maka harga saham akan turun sebesar 0,210 persen.

Tabel-4

Output Koefisen Korelasi dan Determinasi PBV Model Summary

\begin{tabular}{rrrrr}
\hline Model & R & R Square & $\begin{array}{c}\text { Adjusted R } \\
\text { Square }\end{array}$ & $\begin{array}{l}\text { Std.Error of } \\
\text { the Estimate }\end{array}$ \\
\hline 1 & $.340 \mathrm{a}$ & .116 & .090 & .70612 \\
\hline
\end{tabular}

a. Predictors (Constant), PBV

Sumber : data diolah dengan SPSS 25.0

Berdasarkan Tabel-4, dapat diketahui bahwa keeratan hubungan price to book value terhadap harga saham PT Pembangunan Perumahan (Persero) Tbk adalah rendah dan positif. Dengan nilai koefisien korelasi yang diperolah (R) sebesar 0,340. Arah hubungan positif yang diperoleh jika price to book value perusahaan meningkat maka akan meningkatkkan harga saham perusahaan, demikian pula sebaliknya jika price to book value turun maka harga saham akan turun juga.

Price to book value perusahaan hanya mampu memberikan kontribusi terhadap harga saham perusahaan sebesar 0,116 atau secara $11,6 \%$, sedangkan sisanya $88,4 \%$ disumbangkan oleh variabel lain yang tidak diteliti dalam penelitian ini. Uji hipotesis diperoleh $\mathrm{t}$ hitung 2,017>1,690 t tabel berarti ada pengaruh signifikan

\section{KESIMPULAN DAN SARAN}

\section{Kesimpulan}

Berdasarkan hasil penelitian dan pembahasan yang ada, mengenai pengaruh earning per share dan price to book value terhadap harga saham PT Pembangunan Perumahan (Persero) Tbk yang menjadi objek penelitian, maka peniliti dapat mengambil berberapa kesimpulan: 1). Bahwa earning per share dan price to book value berpengaruh signifikan terhadap harga saham PT Pembangunan Perumahan (Persero) Tbk. 2). Bahwa earning per share berpengaruh siginifikan terhadap harga saham PT Pembangunan Perumahan (Persero). 3). Bahwa price to book value berpengaruh signifikan terhadap harga saham PT Pembangunan Perumahan (Persero) Tbk. 


\section{Saran}

1). Bagi perusahaan, karena terbukti bahwa earning per share dan price to book value secara simultan maupun secara parsial berpengaruh positif signifikan terhadap harga saham, maka sebaiknya perusahaan mempertahankan kinerja keuangan perusahaan untuk dapat memperoleh laba yang tinggi untuk menarik minat investor dalam menanamkan modalnya pada perusahaan. Semakin banyak investor yang menanamkan modalnya maka harga saham perusahaan akan meningkat. 2). Bagi investor, sebelum membeli saham suatu perusahaan sebaiknya memperhatikan nilai earning per share dan price to book value yang mempunyai pengaruh signifikan terhadap harga saham pada penelitian ini. 3). Bagi peneliti selanjutnya, sebaiknya menambah variabel penelitian, memperluas sampel penelitian, seperti menjadikan seluruh perusahaan dalam sektor kontruksi bangunan yang terdaftar di Bursa Efek Indonesia dan menambah periode penelitian.

\section{DAFTAR PUSTAKA}

Aisyatur, Rodiyah Winda \& Sri Sulasmiyati, Pengaruh Return On Investment (ROI), Return On Equity (ROE), Earning Per Share (EPS) dan Economic Value Added (EVA) Terhadap Harga Saham, Jurnal Administrasi Bisnis, Vol. 59, No.1, Hal. $125-133$.

Author, (2019), Pembangunan Perumahan, Diakses pada 18 Mei 2019, https:Jli<Lm.wikipedia.org/wiki/Pembangunan_Perumahan.

, (2019), Annual Report, Diakses pada 18 Mei 2019, https://www.ptpp.com/investor-relation/annuaJ-report.

Badan Pusat Statistik, (2019), Produk Domestik Bruto Indonesia Triwulanan 20142018, Jakarta.

Bursa Efek Indonesia, (2019), http://www.idx.co.id.

Darmadji \& Fakhruddin, 2011, Pasar Modal di Indonesia, edisi 3, Salemba Empat, Jakarta.

Dominic, H,T, (2008), Berinvestasi di Bursa Saham, Jakarta, Elex Media Komputindo.

Hanafi, Mamduh M, (2015), Manajemen Keuangan, Yogyakarta BPFE, Yogyakarta Hartono, Jogiyanto, (2016), Teori Portofolio dan Analisis Investasi, Edisi Kesepuluh, Yogyakarta : BPFE.

Husein, Umar, (2011), Metode Penelitian Untuk Skripsi dan Tests Bisnis, Edisi Kesebelas, Jakarta: PT Raja Grafmdo Persada.

Husnan, Suad \& Enny Pudjiastuti, (2015), Dasar-Dasar Manajemen Keuangan, Edisi Ketujuh, Yogyakarta: UPPN STIM YKPN.

Kasmir, (2018), Analisis Laporan Keuangan, Edisi Satu, Cetakan 11, Depok: Rajawali Pers.

Khairani, Imelda, (2016, Mei), Pengaruh Earning Per Share (EPS) dan Dividen Per Share Terhadap Harga Saham Perusahaan Pertambangan Yang Terdaftar di Bursa Efek Indonesia (BEl) Tahun 2011-2013, Jurnal Manajemen dan Keuangan, Vol. 5, No.I.

Moeljadi, (2006), Manajemen Keuangan 1 Pendekatan Kuantitaf dan Kualitatif Malang: Bayumedia. 
Najmiyah. Sujana, Edy. Sinarwati, Ni Kadek. 2014. Pengaruh Price To Book Value (PBV), Price Earning Ratio (PER) dan Debt To Equity Ratio (DER) Terhadap Return Saham Pada Industri Real Estate dan Property yang Terdaftar di Bursa Efek Indonesia Periode 2009-2013. E-Journal S1 Ak Universitas Pendidikan Ganesha Jurusan Akuntansi Program S1. Vol. 2, No. 1.

Putra, I Wayan luniastana Wiagustini, (2014), Pengaruh Leverage dan Profitabilitas Terhadap Kebijakan Dividen dan Nilai Perusahaan. E-Jumal Manajemen Universitas Udayana, Vol. 3, No.9.

Sartono, Agus, (2010), Manajemen Keuangan Teori dan Aplikasi, Edisi Keernpat, Yogyakarta: BPFE.

Siswoyo, Sony, (2013), Analisis Fundamental dan Teknikal Untuk Profit Lebih Maksimal, Jakarta: Gramedia.

Sugiyono, (2016), Statistika Untuk Penelitian, Bandung: Alfabeta.

Syamsuddin, Lukman, (2013), Manajemen Keuangan Perusahaan, Edisi Baru, Cetakan Keduabelas, Jakarta: Rajawali Pers.

Tandelilin, Eduardus. 2010. Portofolio dan Investasi Teori dan Aplikasi. Edisi Pertama. Yogyakarta: KANISIUS.

Yustina Wahyu Cahyaningrum dan Tiara Widya Antikasari. (2015). Pengaruh Earning Per Share, Price to Book Value, Return on Asset, dan Return on Equity Terhadap Harga Saham Sektor Keuangan. 